\title{
Dabigatran-etaxilát: Nově schválená indikace léčby a prevence rekurence hluboké žilní trombózy a plicní embolie
}

\begin{abstract}
Velkým lákadlem na XXI. kongresu České internistické společnosti (Brno, 15.-18. 10. 2014) bylo symposium věnované nové indikaci dabigatran-etexilátu. Na symposiu byla navíc slavnostně představena a pokřtěna kniha autorů MUDr. Terezie Švarcové (I. interní kardioangiologická klinika, LF UK a FN Hradec Králové) a prim. MUDr. Jiř́ho Veselého (Interní oddělení, Nemocnice Náchod) Antikoagulační léčba u fibrilace síní. Jak řekl recenzent knihy prof. MUDr. Jiří. Vítovec, CSc. (I. interní kardioangiologická klinika, LF MU a FN u sv. Anny, Brno), záměrem této publikace je stát se praktickou pomůckou. Praktickým aspektům účinného a bezpečného podávání dabigatranu v indikaci původní, tedy v prevenci CMP u pacientů s nevalvulární fibrilací síní, i v indikaci nové věnoval prim. Veselý i svou přednášku, kterou pod předsednictvím prof. MUDr. Miloše Táborského, Ph.D. (I. interni klinika - kardiologická, LF UP a FN Olomouc) navázal na sdělení prof. MUDr. Aleše Linharta, DrSc., a doc. MUDr. Debory Karetové, CSc. (oba Il. interní klinika kardiologie a angiologie, 1. LF UK a VFN, Praha). Atraktivní obsah symposia se odrazil ve velmi vysoké návštěvnosti.
\end{abstract}

\section{Před pěti lety přinesl dabigatran revoluci do antikoagulační léčby}

Jak připomněl prof. Linhart, fibrilace síní (FS) je nejčastější arytmií, která několikanásobně zvyšuje riziko cévní mozkové príhody (CMP) a je zodpovědná zhruba za jednu třetinu všech CMP. Velmi účinným lékem v prevenci CMP u FS je warfarin. Jeho omezením je nutnost udržování INR (mezinárodního normalizovaného poměru) v cílovém rozmezí 2-3, které je optimální pro dosažení dostatečné účinnosti a minimálního rizika krvácivých komplikací. Řada indikovaných pacientů však hlavně z důvodu rizika krvácení warfarin nedostává, protože se u nich nedaří INR udržovat v cílovém rozmezí z různých všeobecně známých důvodů. Proto jsou v aktualizovaných guidelines Evropské kardiologické společnosti (ESC) pro léčbu FS z roku 2012 doporučena jako léky první volby nová perorální antikoagulancia (NPA).

Pout prvního z NPA, dabigatranu, začala v roce 1992 preklinickým vývojem a od roku 2004 pokračovala rozsáhlým klinickým programem studií, jehož součástí byla i studie RE-LY zahrnující přes 18000 nemocných ze 44 zemí. Studie RE-LY byla ukončena v roce 2009 a přinesla dnes dobře známé výsledky, které ukázaly superioritu dabigatranu $150 \mathrm{mg}$ dvakrát denně $(-35 \%)$ a non-inferioritu dabigatranu $110 \mathrm{mg}$ dvakrát denně $\mathrm{v}$ prevenci CMP a systémové embolie (SE) oproti warfarinu, a to vždy při velmi významném snížení rizika intrakraniálního krvácení (-59\%/-70\%). Důvod pro podávání antikoagulační léčby pacientům $\mathrm{s} F \mathrm{FS}$ je ochrana před ischemickou CMP a dabigatran v dávce $150 \mathrm{mg}$ dvakrát denně, zatím jako jediný z NPA, snížil riziko ischemické a zároveň hemoragické CMP. Prodloužení studie RE-LY nazvané RELY-ABLE $s$ délkou sledování až 6,7 roku potvrdilo účinnost a bezpečnost dabigatranu při dlouhodobé léčbě se srovnatelným snižením rizika CMP/SE a prevencí intrakraniálního krvácení.

Tyto výsledky z randomizovaných kontrolovaných studií byly dále prostřednictvím registrů porovnávány s výsled$k y$ dosaženými $v$ běžné klinické praxi. Americký Úřad pro kontrolu potravin a léků (Food and Drug Administration - FDA) zveřejnil v tomto roce výsledky z databáze Medicare zahrnující přes 134000 nemocných starších 65 let, které se velmi těsně podobají známým výsledkưm studie RE-LY (pokles mortality, ischemických CMP, intrakraniálních krvácení). Jedinou výjimkou byl nižší výskyt infarktu myokardu (IM) při léčbě dabigatranem v porovnání s warfarinem, který rozptýlil obavy z mírného nárůstu incidence IM při léčbě dabigatranem pozorovaného ve studii RE-LY (obr. 1). Tyto obavy dále vyvrátily výsledky dánského registru s téměř 13000 pacienty sledovanými průměrně 16 měsíců, ve kterém obě dávky dabigatranu vykázaly nevýznamně nižší incidenci IM v porovnánís warfarinem.

Př́běh dabigatranu ale pokračuje dál. Subanalýza studie RE-LY testovala hypotézu, zda by NPA nemohla být př́nosem i z hlediska tzv. warfarinem navozené nefropatie. Výsledky prezentované na kongresu ESC v září 2014 ukázaly, že u pacientů léčených ve studii alespoň 30 měsíců byl pokles glomerulární filtrace (GFR) v průběhu
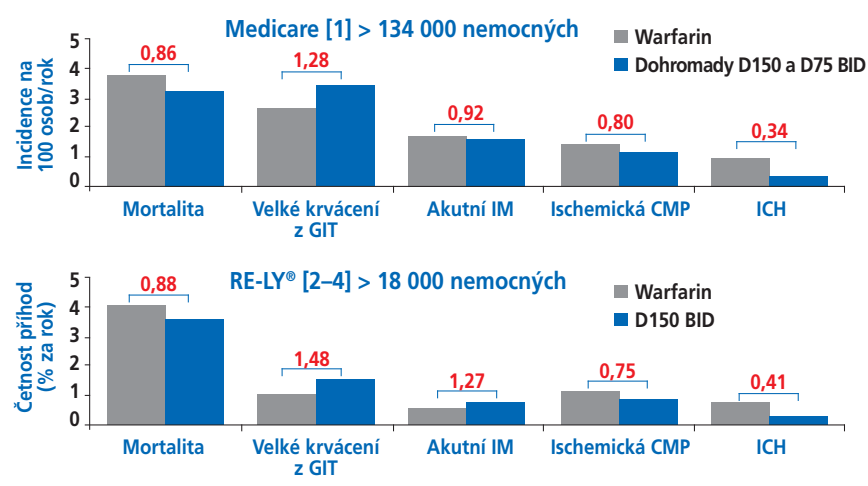

Obr. 1 - Nezávislá analýza FDA databáze Medicare [1] je srovnatelná s výsledky RE-LY® [2-4].

BID - dvakrát denně; CMP - cévní mozková příhoda; GIT - gastrointestinální trakt; ICH - intrakraniální krvácení; IM - infarkt myokardu. 


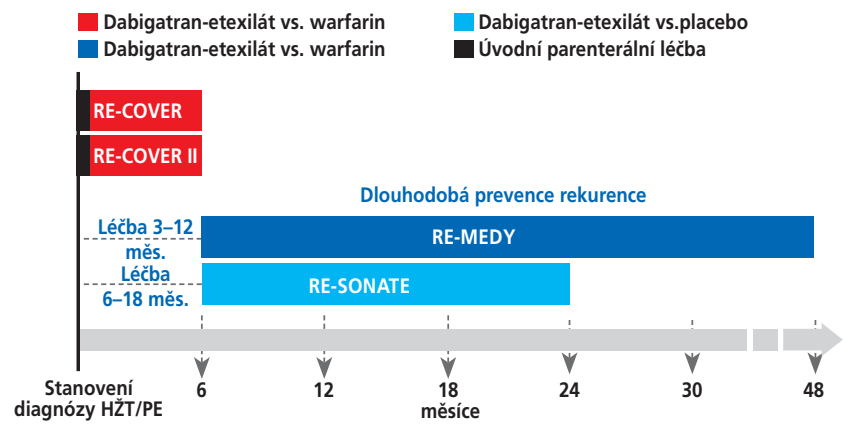

Obr. 2 - Program hodnocení dabigatranu u tromboembolické nemoci. HŽT - hluboká žilní trombóza; PE - plicní embolie.

studie při léčbě oběma dávkami dabigatranu významně nižší než u warfarinu. Stejný výsledek byl zjištěn i u diabetiků při dávce dabigatranu $150 \mathrm{mg}$.

V závěru se prof. Linhart zabýval myšlenkou výhod dávkování jednou nebo dvakrát denně. Ukázal na prríkladu HIV pozitivních pacientů léčených inhibitory proteáz, že jedna zmeškaná dávka při podávání jednou denně má stejný farmakokinetický vliv jako dvě až tři zmeškané dávky při režimu dvakrát denně. Metaanalýza publikovaných studií s NPA s neprrímým porovnáním těchto režimů ukázala lepší účinnost i bezpečnost dávkování dvakrát denně.

\section{Dabigatran prokázal účinnost a bezpečnost v léčbě a prevenci rekurence hluboké žilní trombózy a plicní embolie}

Studie, které prokázaly účinnost a bezpečnost dabigatranu v jeho nové indikaci, představila účastníkưm kongresu doc. Karetová. Připomněla, že cílem léčby tromboembolické nemoci (TEN) je prevence krátkodobých komplikací (růst a migrace trombu), dlouhodobých následků (posttrombotický syndrom, chronická tromboembolická plicní hypertenze) a prevence recidiv hluboké žilní trombózy (HŽT) či plicní embolie (PE).

Dabigatran v dávce 150 mg dvakrát denně byl v akutní léčbě TEN hodnocen ve dvou identických šestiměsíčních studiích nazvaných RE-COVER a RE-COVER II, kdy byla léčba dabigatranem zahájena po iniciální pěti- až desetidenní léčbě nízkomolekulárním heparinem (LMWH), a dále v prevenci rekurence TEN ve dvou studiích RE-MEDY a RE-SONATE (obr. 2). Hlavními sledovanými parametry byla

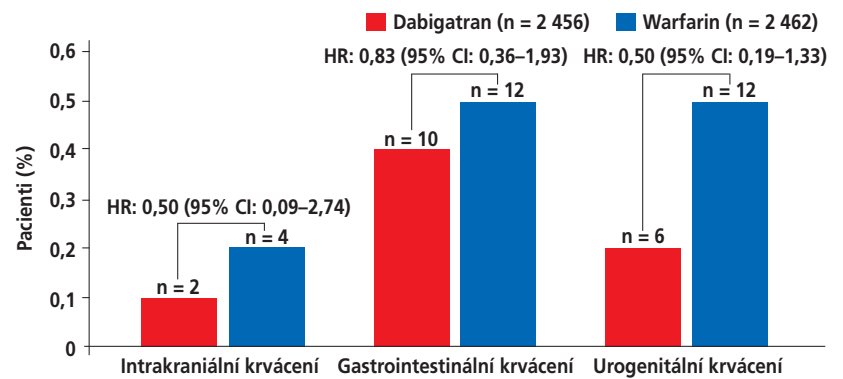

Obr. 3 - Dabigatran-etexilát vs. warfarin: nižší výskyt závažných intrakraniálních, gastrointestinálních a urogenitálních krvácení [5] vždy recidiva tromboembolické příhody a související mortalita a incidence krvácení.

Sdružená data ze studií RE-COVER a RE-COVER II prokázala non-inferioritu dabigatranu vůči warfarinu z hlediska hodnocené účinnosti a významné snížení závažných krvácení (-40 \%) včetně jeho jednotlivých typů (obr. 3), závažných nebo klinicky významných krvácení (-44 \%) i všech krvácení $(-33 \%)$ při léčbě dabigatranem. Studie RE-MEDY porovnávala dabigatran s warfarinem u pacientů, u nichž po tří- až dvanáctiměsíční úvodní antikoagulační léčbě přetrvávalo zvýšené riziko recidivy TEN, a to po dobu až 36 měsíců. Prokázala non-inferioritu dabigatranu vưči warfarinu v prevenci recidivy/fatální TEN při numericky nižším výskytu závažných krvácení (-48\%), významně nižším výskytu závažných nebo klinicky relevantních krvácení (-46 \%) i jakýchkoliv krvácení (-29\%). Výskyt kardiovaskulárních příhod byl u pacientů užívajících dabigatran vyšší, ovšem je třeba uvést, že tito pacienti byli více rizikoví, protože do ramene s dabigatranem bylo randomizováno statisticky významně více pacientů s anamnézou ICHS, hypertenzí a diabetem. Do studie RE-SONATE, kde byl dabigatran porovnáván s placebem, byli zařazeni pacienti po úvodní šesti- až osmnáctiměsíční antikoagulační léčbě, u nichž byla zvažována nutnost další antikoagulace. Dabigatran zajistil velmi významné snížení incidence recidivy symptomatické/fatální TEN o $92 \%$ (obr. 4) a navíc toto snížené kumulativní riziko TEN oproti placebu přetrvávalo i po dobu jednoho roku po ukončení léčby (obr. 5). Výskyt krvácení byl u dabigatranu nízký, incidence kardiovaskulárních príhod byla srovnatelná s placebem.

Jak shrnula doc. Karetová: „Dabigatran je tedy novou terapeutickou možností v léčbě HŽT a PE, kde nabízí po

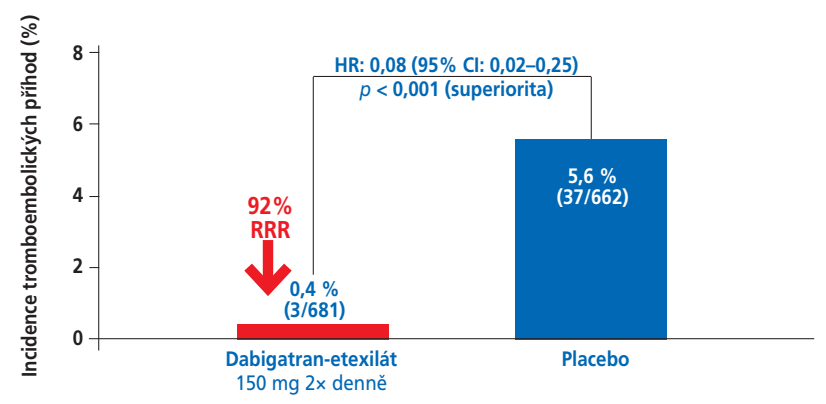

Obr. 4 - Snižení výskytu recidiv symptomatické/fatální tromboembolické nemoci při podávání dabigatranu v porovnání s placebem [6]

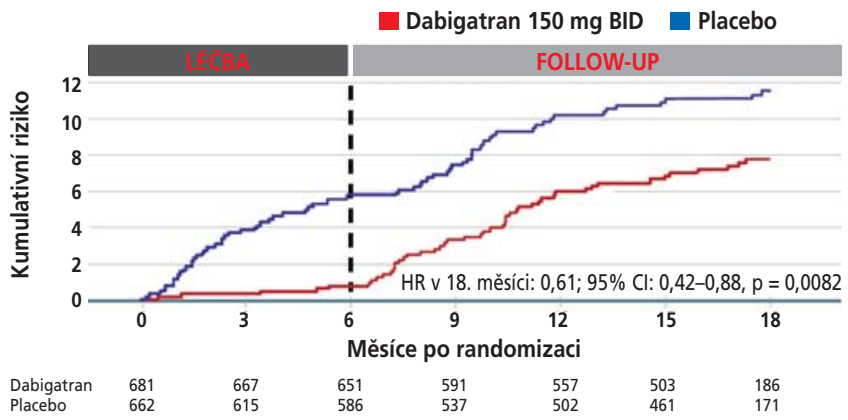

Obr. 5 - Snížení rizika recidiv TEN přetrvává i jeden rok po ukončení léčby dabigatranem [6]. BID - dvakrát denně; TEN - tromboembolická nemoc. 
úvodní léčbě LMWH jednoduché podávání bez povinné úpravy dávky a monitorování."

\section{Při podávání dabigatranu u tromboembolické nemoci platí v praxi stejná pravidla jako v indikaci prevence CMP u pacientů s fibrilací síní}

Praktickým otázkám podávání dabigatranu v léčbě a prevenci recidiv HŽT/PE se věnoval prim. Veselý. Uvedl, že akutní léčba dabigatranem po úvodní minimální pětidenní parenterální antikoagulaci LMWH je jednoduchá, protože pro dabigatran-etexilát platí stejná pravidla jako $v$ indikaci prevence CMP $u$ pacientů s FS. U TEN se všeobecně LMWH podávají v případě podezření na TEN před stanovením definitivní diagnózy, u závažnějších forem HŽT, při PE a u hospitalizovaných pacientů. Pro navazující perorální léčbu dabigatranem platí stejná doporučení jako u FS: základní dávkování pro většinu pacientů je 150 mg dvakrát denně a snížená dávka 110 mg dvakrát denně vždy u pacientů od 80 let věku nebo při současném užívání verapamilu, a po zvážení rizika tromboembolie ve srovnání s rizikem krvácením také u pacientů ve věku 75-80 let, se středně závažnou poruchou renálních funkcí (clearance kreatininu 30-50 $\mathrm{ml} / \mathrm{min}$ ), s gastritidou/ezofagitidou, gastroezofageálním refluxem nebo se zvýšeným rizikem krvácení. Dabigatran je kontraindikován při clearance kreatininu $<30 \mathrm{ml} / \mathrm{min}$. Před zahájením a v průběhu léčby dabigatranem je třeba monitorovat renální funkce. Dle aktuálních doporučení České kardiologické společnosti pro léčbu FS to platí pro všechna NPA. Nedávno publikovaná subanalýza studie RE-LY ukázala, že dabigatran v obou dávkách významně snížil pokles renálních funkcí v porovnání s warfarinem, ani on však pokles GFR zcela nezastavil. Účinnost a bezpečnost dabigatranu je u pacientů s TEN s mírnou až středně závažnou poruchou renálních funkcí zcela zachována.

Při převedení léčby z jiných antikoagulancií na dabigatran se postupuje rovněž stejně jako $v$ indikaci prevence CMP u FS. Při převedení z warfarinu zahájíme léčbu dabigatranem při poklesu INR $<2$, při převedení z LMWH podáme první dávku dabigatranu o 0-2 hodiny dříve, než by vycházela první nepodaná dávka LMWH, a při převedení z kontinuálně podávaného heparinu zahájíme léčbu dabigatranem v době přerušení předchozí antikoagulace.

Výhodou dabigatranu je nízký potenciál lékových interakcí. Kontraindikován je pouze při současném systémovém podávání ketokonazolu, cyklosporinu, itrakonazolu a dronedaronu, nedoporučuje se současné podávání s rifampicinem a karbamazepinem, nižší dávku je třeba podávat pouze při současné léčbě verapamilem a není nutné snižovat dávku, pokud je pacient současně léčen chinidinem, amiodaronem nebo klarithromycinem. Na základě výsledků sdružených dat studií RE-COVER a RE-COVER II nebyla u dabigatranu zjištěna žádná závažná interakce při užívání nesteroidních antirevmatik (NSAID) nebo nízkých dávek kyseliny acetylsalicylové (obr. 6). Výskyt závažných nebo klinicky významných krvácení byl u této kombinace podobný nebo nižší než u warfarinu.

Při chirurgických a invazivních výkonech se léčba dabigatranem přerušuje opět stejně jako v indikaci preven-
Žádná významná interakce při uživání NSAID nebo nízkých dávek ASA

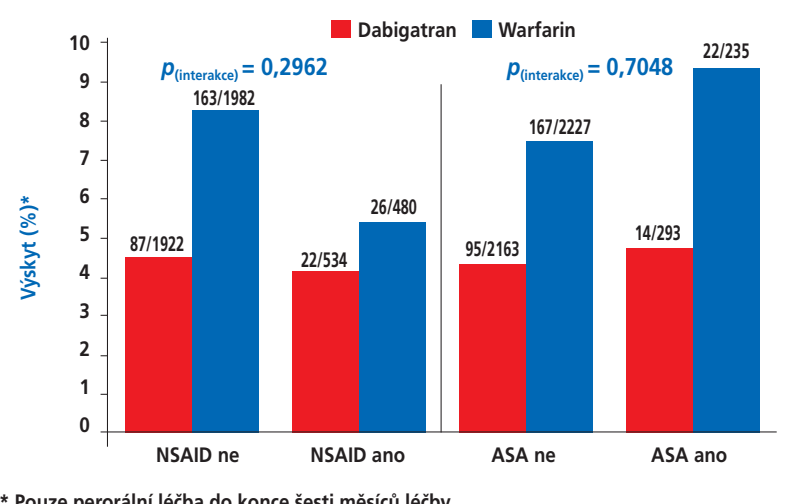

Obr. 6 - Sdružená data studií RE-COVER/RE-COVER II: Závažná nebo klinicky významná nezávažná krvácení při současném užívání NSAID nebo kyseliny acetylsalicylové [7]

ASA - kyselina acetylsalicylová; NSAID - nesteroidní antirevmatika.

ce CMP u FS 24 hodin před běžným výkonem v případě normální renální funkce, dva až čtyři dny před rozsáhlým výkonem, v prípadě vysokého rizika krvácení nebo při poruše renální funkce. Při akutním výkonu je nutno zjistit podání poslední dávky, a pokud je to možné, odložit výkon, aby odstup činil nejméně 12 hodin. Opětovné zahájení léčby dabigatranem je doporučeno co nejdříve, jakmile to umožní klinický stav pacienta a je dosaženo adekvátní hemostázy.

Antikoagulační účinek dabigatranu je možné orientačně sledovat pomocí běžného testu aPTT, jehož hodnoty by měly $v$ době minimální koncentrace dabigatranu odpovídat přibližně 1,5násobku normálních hodnot, nebo stanovením plazmatické koncentrace dabigatranu pomocí testu Hemoclot ${ }^{\circledR}$, kdy je zvýšené riziko krvácení při minimálních hodnotách > 200 ng/ml. V případě krvácení při léčbě TEN dabigatranem platí stejná pravidla jako v indikaci FS, tj. stejná opatření jako při krvácení v případě užívání warfarinu s výjimkou podání vitaminu K.

Pacienta léčeného dabigatranem je třeba vždy edukovat o rizicích souvisejících s užíváním antikoagulační léčby a předat mu Informační kartu, kde jsou uvedena rizika a důvody nutného pravidelného užívání a která poskytne informace, co dělat v prípadě krvácení.

Prim. Veselý zakončil svoji přednášku dvěma stručnými praktickými doporučeními pro léčbu TEN.

1) Pro lékaře, kteří nemají zkušenosti s dabigatranem: po nejméně pěti dnech iniciální parenterální antikoagulace zahajujeme akutní léčbu dabigatranem v dávce $150 \mathrm{mg}$ nebo $110 \mathrm{mg}$ dvakrát denně. Tyto dvě dávky umožňují individualizaci léčby. Nižší dávku 110 mg dvakrát denně musejí užívat pacienti starší 80 let nebo pacienti léčení verapamilem a zvažujeme ji u pacientů s rizikem krvácení. Před zahájením léčby je nutné zhodnotit renální funkce. Z warfarinu převádíme při INR < 2. Dưležitá je edukace pacienta.

2) Pro lékaře, kteří mají zkušenosti s dabigatranem v indikaci prevence CMP u FS: po iniciální nejméně pětidenní léčbě parenterálním antikoagulanciem zůstává postup léčby dabigatranem úplně stejný jako v dosavadní zavedené indikaci. 
Informace, které si účastníci symposia odnesli domů, shrnul prof. Táborský. Dabigatran je zatím jediným NPA s prokazatelně větším snížením incidence ischemických CMP a nižším rizikem hemoragických CMP v porovnání s warfarinem. Po randomizované kontrolované studii RE-LY a jejím prodloužení RELY-ABLE potvrdily účinnost a bezpečnost dabigatranu nezávislé analýzy registrů při používání dabigatranu $v$ reálné praxi. Pochybnosti týkající se mírně vyšší incidence IM v klinických studiích se $v$ registrech nenaplnily. Poplašné zprávy o krvácivých komplikacích se ukázaly při porovnání s warfarinem jako neopodstatněné. Nové post-hoc analýzy studie RE-LY naznačují menší pokles renálních funkcí při léčbě dabigatranem v porovnání s warfarinem. V klinické praxi disponuje dabigatran výhodou dvojího dávkování 150 mg a 110 mg bez nutnosti monitorování.

Dabigatran je nově indikován v léčbě a sekundární prevenci HŽT/PE. Jeho účinnost a bezpečnost v této indikaci byla prověřena $v$ akutní fázi i při dlouhodobé léčbě. V akutní léčbě byla prokázána non-inferiorita dabigatranu vůči warfarinu a významně méně krvácení. U dlouhodobě léčených v prevenci rekurence TEN byla prokázána superiorita proti placebu a na rozdíl od ostatních NPA byl dabigatran testován i proti warfarinu v nejdelším sledová- ní trvajícím až 36 měsíců a byla zachována non-inferiorita při signifikantně nižším výskytu závažných nebo klinicky významných krvácení. Po úvodní minimálně pětidenní léčbě LMWH nabízí dabigatran jednoduché dávkování bez povinné úpravy dávky. $\mathrm{V}$ praxi platí pro dabigatran $v$ léčbě a prevenci recidiv TEN stejná pravidla jako v indikaci prevence CMP u pacientů s FS.

Připravila MUDr. Zuzana Zafarová

\section{Literatura}

[1] http://www.fda.gov/Drugs/DrugSafety/ucm396470.htm

[2] S.J. Connolly, M.D. Ezekowitz, S. Yusuf, et al., Dabigatran versus warfarin in patients with atrial fibrillation, New England Journal of Medicine 361 (2009) 1139-1151.

[3] S.J. Connolly, M.D. Ezekowitz, S. Yusuf, et al., Newly identified events in the RE-LY trial, New England Journal of Medicine 363 (2010) 1875-1876.

[4] Pradaxa®: EU SPC, 2014.

[5] S. Schulman, A.K. Kakkar, S.Z. Goldhaber, et al., Treatment of acute venous thromboembolism with dabigatran or warfarin and pooled analysis, Circulation 129 (2014) 764-772.

[6] S. Schulman, C. Kearon, A.K. Kakkar, et al., Extended use of dabigatran, warfarin, or placebo in venous thromboembolism, New England Journal of Medicine 368 (2013) 709-718.

[7] S. Schulman, et al., Abstract 1136. Presented at ASH 2013. 